\title{
Diversity of Meloidogyne incognita populations from cotton and aggressiveness to Gossypium spp. accessions
}

\author{
C. M. L. Lopes ${ }^{a b *}$ (D) J. E. Cares ${ }^{a}$, F. J. Perina ${ }^{c}$, G. F. Nascimento ${ }^{b}$ \\ J. S. F. Mendonça ${ }^{b}$, A. W. Moita ${ }^{d}$, P. Castagnone-Sereno ${ }^{e}$ and R. M. D. G. Carneiro ${ }^{b}$ (D) \\ aprograma de Pós-Graduação em Fitopatologia, Universidade de Brasília, Brasília, DF 70910-900; ' Embrapa Centro de Recursos \\ Genéticos e Biotecnologia, Brasília, DF 70849-970; 'Embrapa Algodão, Campina Grande, PB 58428-095; ' Embrapa Hortaliças, Brasília, \\ DF 70359-970, Brazil; and 'INRA, INRA-UMR 1355, UNS, CNRS-UMR 7254, Institut Sophia Agrobiotech, 400 route des Chappes BP167, \\ 06903 Sophia Antipolis, France
}

The root-knot nematode (RKN) Meloidogyne incognita is the main nematode causing losses to the cotton crop in Brazil. In order to implement control strategies within integrated management, an accurate identification of the nematode populations prevailing in the cotton production areas is necessary. This study aimed to assess the genetic variability and aggressiveness of RKN populations from cotton production areas in Bahia state, Brazil. All populations were characterized biochemically and molecularly and identified as M. incognita. RAPD and AFLP markers detected $44 \%$ of polymorphic fragments among the 13 populations of this species. The $10 \mathrm{M}$. incognita populations collected in Bahia presented $33.7 \%$ of diversity when compared to each other, and $25 \%$ when the population from Barreiras (the most polymorphic) was excluded. This polymorphism increased when populations from other Brazilian states were included. The aggressiveness and virulence among populations from Bahia towards different cotton accessions (susceptible/resistant) was also studied. None of the populations showed virulence against the moderately resistant (Clevewilt 6, Wild Mexican Jack Jones and LA 887) and highly resistant (CIR1348 and M-315 RNR) cultivars. Two M. incognita populations from Barreiras were the most aggressive, reaching reproduction factors of 539 and 218, respectively, in the susceptible cultivar FiberMax 966. The most aggressive population (8) was also the most genetically divergent in phylogenetic analyses. These results demonstrate that diversity of $M$. incognita populations from cotton farms in Bahia is not related to virulence against resistant accessions, which suggests that cultivars containing one or two resistance genes with good agronomic characteristics could be used in infested commercial areas in Bahia state, Brazil.

Keywords: AFLP, Gossypium spp., pathogenicity, RAPD, resistance, RKN management

\section{Introduction}

Several diseases and pests affect cotton (Gossypium spp.) yield worldwide. In Brazil, the main nematode causing yield losses in the cotton crop is the root-knot nematode (RKN) Meloidogyne incognita, which stands out due to its wide distribution, survival capacity, and a wide range of host plants. The yield losses caused by this RKN species are higher in sandy soils with low fertility, and when it is found in association with the cotton wilt-causing agent, the fungus Fusarium oxysporum f. sp. vasinfectum, inducing the Fusarium-nematode disease complex (Wang \& Roberts, 2006). The occurrence of high levels of M. incognita populations can make cotton cultivation unfeasible, with reports of abandonment of infested areas in São Paulo, Paraná and Goiás states (Galbieri et al., 2015). Bahia is the second largest cotton-growing state

*E-mail: carinallopes@hotmail.com

Published online 27 February 2019 in Brazil, with $94 \%$ of the production in the western region, and has suffered severe losses due to the attack of this nematode (CONAB, 2018). In Brazil, most commercial cotton cultivars are susceptible to this RKN species, and only a few are moderately resistant or resistant (Silva et al., 2014).

The cotton American line Auburn 623 RNR, resistant to M. incognita, has been available for over 40 years (Shepherd, 1974), from which the M-315 RNR line is derived, widely used in studies as a source of high resistance to this pathogen. The high resistance observed in Auburn 623 RNR has an oligogenic inheritance that is determined by at least two genes located on chromosomes 11 and 14. This line originated from the cross between two moderately resistant accessions: Clevewilt 6 and Wild Mexican Jack Jones (PI 593649). The quantitative trait locus (QTL) qMi-C11, originating from Clevewilt 6 , has an additive gene effect and is located in the CIR069-CIR316 interval on chromosome 11, whereas QTL qMi-C14, which originated from Wild Mexican Jack Jones, has an additive-dominant gene effect and is located in the BNL3545-BNL3661 interval on chromosome 14 (Shepherd, 1974; McPherson et al., 2004; 
Jenkins et al., 2012; He et al., 2014). New sources of resistance are desirable for the development of cultivars with higher levels of resistance to this RKN and less likely to be supplanted by variants of the pathogen. Recently, the accession of Gossypium barbadense (CIR1348) was identified as a new source of high resistance to M. incognita (Mota et al., 2013; Silva et al., 2014). In accession CIR1348 two QTLs were identified, one on chromosome 11 and another on chromosome 15, which are responsible for the high level of resistance to the nematode (Silva et al., 2014; M. Giband, CIRAD, France, personal communication).

The use of resistant cultivars as a strategy in integrated management requires the correct characterization and identification of the nematode populations prevalent in the areas of cotton production, and the characterization of intraspecific genetic diversity among M. incognita populations is important. Within M. incognita species there are physiological races; however, only races 3 and 4 parasitize cotton, with race 3 found most often in commercial production areas (Inomoto, 2001). Although the occurrence of races is recognized in M. incognita, Moens et al. (2009) recommended discontinuation of this terminology, because a small variation among populations of the same species is measured and the range of hosts is very large. The analysis of the aggressiveness and virulence of the nematode populations to a given crop would be the most appropriate strategies.

Parthenogenetic Meloidogyne species such as M. arenaria, M. incognita and M. javanica have a genetic variability that allows rapid adaptation to unfavourable conditions, such as adaptation to resistant host plants (Trudgill \& Blok, 2001). Reports of resistance breakdown in natural nematode populations demonstrates the ability of the pathogen to develop mechanisms of adaptation to resistance genes in the case of continuous use of the same source of resistance (Castagnone-Sereno, 2002). The selection of M. incognita virulent populations after successive resistant cotton plantations has occurred in California (Ogallo et al., 1997) and Texas (Zhou et al., 2000).

With the aim of contributing to breeding programmes for resistance of cotton to $M$. incognita, the objective of this study was to characterize the intraspecific genetic diversity and aggressiveness/virulence of $M$. incognita populations prevailing in cotton production areas in the western region of Bahia state, Brazil. The development and use of cotton cultivars resistant to this RKN species could reduce quantitative and qualitative losses of cotton fibre, in addition to representing an important management strategy in infested areas.

\section{Materials and methods}

\section{Characterization and identification of RKN species and races}

Ten populations of M. incognita were collected in infested cotton (Gossypium spp.) farms from the western part of the state of Bahia (Table 1) and multiplied in tomato (Solanum lycopersicum 'Santa Clara') plants. After 4 months, females were removed from the tomato roots, then identified using esterase (EST) profiles, according to the protocol described by Carneiro \& Almeida (2001), and the races of M. incognita were determined according to Hartman \& Sasser (1985).

\section{Extraction of eggs and genomic DNA}

The extraction of eggs from each population was done according to Carneiro et al. (2004). Total genomic DNA was extracted according to the method described by Randig et al. (2002), quantified and then stored at $-20^{\circ} \mathrm{C}$.

\section{Identification of the Meloidogyne species by SCAR markers}

Confirmation of the identification and purity of the inoculum was done using the SCAR species-specific markers M. incognita Inck14 (Randig et al., 2002) and M. javanica Jav (Ziljstra et al., 2000). The latter was included due to the high incidence of $M$. javanica in the region, especially in areas where soybean is grown in succession to cotton.

\section{Characterization of M. incognita genetic diversity by RAPD markers}

The genetic diversity of Brazilian M. incognita populations was compared using populations from Paraná (PR) and Mato Grosso do Sul (MS) states, studied by Silva et al. (2014), and a population of $M$. enterolobii was included as an out-group (Table 1). RAPD reactions occurred in a volume of $13 \mu \mathrm{L}$ containing 9 ng genomic DNA under the conditions described by Randig et al. (2002). Forty random 10-mer oligonucleotide primers (Operon Technologies; A12, AB1, AB06, AD03, AG04, AU13, C7, C9, F06, G2, G4, G13, J20, K10, K19, L19, M20, N7, N10, P02, P1, P6, Q10, R3, R4, R7, S20, T6, U05, V2, V7, V17, W05, W6, W15, X20, Y05, Y16, Z4, Z17) were used in the analysis. The amplification products were separated by $1.5 \%$ agarose gel electrophoresis following the methodology of Randig et al. (2002), with reactions done in duplicate.

Table 1 Meloidogyne incognita populations and M. enterolobii (M. ent, out-group), their origin (Brazilian municipalities and states), races and esterase phenotypes (EST).

\begin{tabular}{llll}
\hline Population code & Origin & Race & EST \\
\hline 1 & Luís Eduardo Magalhães, BA & 3 & 12 \\
2 & Luís Eduardo Magalhães, BA & 3 & 12 \\
3 & Luís Eduardo Magalhães, BA & 3 & 12 \\
4 & São Desiderio, BA & 3 & 12 \\
5 & Barreiras, BA & 3 & 12 \\
6 & São Desiderio, BA & 3 & 12 \\
7 & São Desiderio, BA & 4 & 12 \\
8 & Barreiras, BA & 3 & 12 \\
9 & Luís Eduardo Magalhães, BA & 3 & 12 \\
10 & Barreiras, BA & 3 & 12 \\
11 & Londrina, PR & 3 & 11 \\
12 & Umuarama, PR & 3 & 12 \\
13 & Dourados, MS & 3 & 12 \\
M. ent & Petrolina, PE & - & VS1-S1 \\
\hline
\end{tabular}

BA, Bahia; PR, Paraná; MS, Mato Grosso do Sul; PE, Pernambuco. 


\section{Characterization of M. incognita genetic diversity by AFLP markers}

Approximately $1 \mu \mathrm{L}$ of genomic DNA was digested by the restriction enzyme EcoRI; adaptors were attached to the ends of the fragments in a final volume of $20 \mu \mathrm{L}$ and incubated overnight at $37^{\circ} \mathrm{C}$ following the recommendations of Suazo \& Hall (1999). The digestion-ligation reactions were diluted with TrisEDTA buffer to a final volume of $200 \mu \mathrm{L}$ and stored at $-20{ }^{\circ} \mathrm{C}$. A series of thirteen 19-mer primers (Integrated DNA Technologies) were used, consisting of EcoRI adapter core sequence $5^{\prime}$-GACTGCGTACCAATTCAGT-3' plus the selective nucleotides AGT, ACT, ATT, GCG, CAG, TGG, CCT, ACC, GCC, CGA, CAT, CTC and CCG. The amplified fragments were separated by electrophoresis on high resolution $1.5 \%$ gel agarose-synergel (Diversified Biotech Synergel) as described by Semblat et al. (1998).

\section{Phylogenetic analysis}

For each marker type, the amplified fragments were recorded as present or absent, and were converted into a binary matrix. Phylogenetic reconstruction was performed using the unweighted pair group method with arithmetic mean (UPGMA), implemented in Paup v. 4 b10 (Swofford, 2002). The stability of the dendrogram nodes was tested by 1000 bootstrap replicates. The percentage of polymorphisms was calculated based on the presence of polymorphic and monomorphic bands in the binary matrices using the formula: $\mathrm{P}=\mathrm{P} /(\mathrm{P}+\mathrm{M}) \times 100$, where $\mathrm{P}=$ polymorphic bands and $\mathrm{M}=$ monomorphic bands.

\section{Aggressiveness/virulence of M. incognita populations on cotton accessions}

\section{Gossypium accessions}

The accessions of G. hirsutum and G. barbadense were obtained from Embrapa Cotton's germplasm collection (Table 2). These accessions were previously studied and shown to be moderately to highly resistant to populations of $M$. incognita races 3 and 4 (Mota et al., 2013; Silva et al., 2014). Gossypium hirsutum 'FiberMax 966' was used as a susceptible control, while G. hirsutum breeding line M-315 RNR was used as a resistant control.

\section{Nematode inoculum}

Six of the 10 populations collected in the state of Bahia were selected for the study of aggressiveness/virulence, based on the information of genetic variability and geographic distribution. Prior to inoculation, the populations were multiplied on tomato cv. Santa Clara for 3 months under greenhouse conditions. Eggs were extracted from infected roots using $0.5 \% \mathrm{NaOCl}$, according to Hussey \& Barker (1973), using a blender instead of manual agitation.

\section{Evaluation of nematode resistance in greenhouse conditions}

Seven plants of each cotton accession were grown in pots $(20 \times 15 \mathrm{~cm})$ filled with a mixture of autoclaved soil and Bioplant compost $(1: 1)$ and maintained at $25-30{ }^{\circ} \mathrm{C}$ under greenhouse conditions. Twenty-five days after seedling emergence, pots were inoculated with 5000 eggs of M. incognita. Plants were arranged in a randomized block design, and watered and fertilized as needed. Three months after inoculation, the root
Table 2 Gossypium spp. accessions.

\begin{tabular}{|c|c|c|}
\hline Accession name & Species & Origin - accession number \\
\hline CIR1348 & $\begin{array}{l}\text { G. barbadense } \\
\text { race barbadense }\end{array}$ & $\begin{array}{l}\text { Peru - wild accession; } \\
\text { CIRAD CIR1348 }\end{array}$ \\
\hline Clevewilt 6 & G. hirsutum & $\begin{array}{l}\text { USA - obsolete cultivar } \\
\text { with the resistance locus } \\
\text { qMi-C11 to RKN }\end{array}$ \\
\hline $\begin{array}{l}\text { Wild Mexican Jack } \\
\text { Jones }\end{array}$ & G. hirsutum & $\begin{array}{l}\text { Mexico - wild accession, } \\
\text { with the resistance locus } \\
\text { qMi-C14 to RKN. NPGS } \\
\text { PI } 593649\end{array}$ \\
\hline LA 887 & G. hirsutum & $\begin{array}{l}\text { USA - obsolete cultivar with } \\
\text { resistance to RKN }\end{array}$ \\
\hline M-315 RNR & G. hirsutum & $\begin{array}{l}\text { USA - breeding line with the } \\
\text { resistance loci qMi-C11 and } \\
\text { qMi-C14 to RKN }\end{array}$ \\
\hline FiberMax 966 & G. hirsutum & $\begin{array}{l}\text { Australia - commercial } \\
\text { variety susceptible to RKN }\end{array}$ \\
\hline
\end{tabular}

CIRAD, French Agricultural Research Centre for International Development; NPGS, National Plant Germplasm System; RKN, root knot nematodes.

systems were rinsed under tap water and weighed, stained with phloxine B and evaluated for gall (GI) and egg mass (EMI), categorized as 1: 1-2 galls or egg masses; 2 : 3-10 galls or egg masses; 3: 11-30 galls or egg masses; 4: 31-100 galls or egg masses; and 5: >100 galls or egg masses per root system (Hartman \& Sasser, 1985). Eggs were extracted using the same methodology, and $1 \% \mathrm{NaOCl}$. The reproduction factor $(\mathrm{RF})$ was calculated as $\mathrm{RF}=\mathrm{FP} / \mathrm{IP}$, where $\mathrm{FP}=$ final population and IP = initial population $(5000$ eggs $)$. The average RF was transformed as $\log (x+1)$, submitted to analysis of variance and the means grouped using Scott-Knot's test $(P<0.05)$.

\section{Results}

\section{Characterization/identification of RKN species and races}

All populations from western Bahia exhibited M. incognita phenotype EST I2 with two bands, a major band ( $\mathrm{Rm} 1.1)$ and a minor band (Rm 1.2; Fig. 1a, Table 1). The specific SCAR markers of M. incognita (Inck14) and $M$. javanica (Jav) confirmed the identification and purity of M. incognita populations (Fig. 1b). The $10 \mathrm{M}$. incognita populations from Bahia varied in their response to resistant tobacco NC95; population 7 from São Desiderio reproduced on tobacco and was classified as belonging to race 4 , whereas populations $1,2,3,4,5,6,8,9$ and 10 did not, and were assigned to race 3 (Table 1 ).

\section{Genetic diversity}

The number of reproducible amplified fragments varied from 10 to 30 per primer and their size ranged from 200 to $4000 \mathrm{bp}$; a total of 820 amplified fragments were scored for both RAPD and AFLP markers (Fig. 2a,b) and 361 were polymorphic. The cluster analysis, using RAPD and AFLP markers, revealed that $44 \%$ of polymorphic fragments were 
(a)
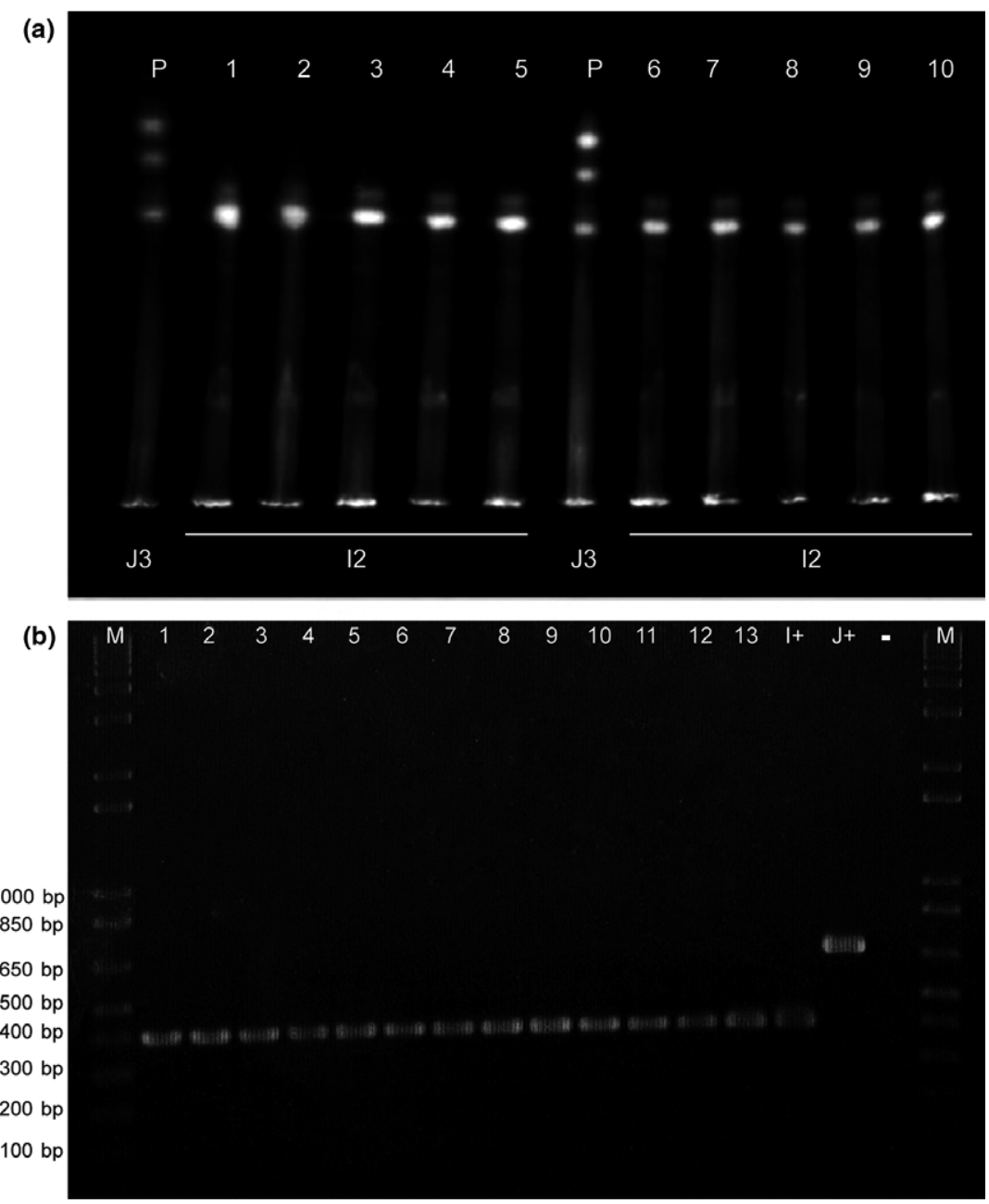

Figure 1 (a) Esterase phenotypes of Meloidogyne incognita (EST I2) 1-10: isolates from Bahia. P: M. javanica pattern (EST J3) included as reference. (b) PCR amplification patterns of Meloidogyne spp. generated with specific SCAR primers inc-K14-F/R (Randig et al., 2002). 1-10: isolates from Bahia; 11 and 12: isolates from Paraná; 13: isolate from Mato Grosso do Sul; (I+, J+): positive controls, M. incognita and M. javanica, respectively; (-): DNA negative control; M: 1 kb Plus DNA ladder (Invitrogen); bp: base pairs.

among the 13 populations. The 10 populations of M. incognita from Bahia presented a diversity of $33.7 \%$ when compared to each other and $25 \%$ when population 8 from Barreiras, the most polymorphic, was excluded. This polymorphism increased when populations from other Brazilian states Paraná and Mato Grosso do Sul were included (Table 3). The dendrogram resulting from the concatenation of the RAPD and AFLP datasets is shown in Figure 3. All populations of $M$. incognita clustered together with $89 \%$ bootstrap support; however, population 8 from Bahia and 13 from Mato Grosso do Sul proved to be the most genetically distinct. The populations from Paraná (11 and 12 ) were the closest, with $100 \%$ bootstrap support.

\section{Aggressiveness and virulence of $M$. incognita populations on cotton accessions}

Aggressiveness and virulence were evaluated using the criteria of resistance and susceptibility: GI, EMI, number of eggs per $\mathrm{g}$ of roots and RF. All nematode populations showed reduced RF $(<0.7)$ on the resistant accessions M-315 RNR and CIR1348 (with two resistance QTLs; Table 4). Gall and egg mass formation were also partially suppressed on these cotton accessions (Table 5). The other three cultivars (Wild Mexican Jack Jones, LA 887 and Clevewilt 6) with a single resistance gene (moderate resistance) were also resistant using the Hussey \& Janssen (2002) concept, which predicts reproduction for the resistant accession as $<10 \%$ of the susceptible accession. Considering this concept, none of the populations from Bahia was virulent to the five cotton cultivars with different resistance genes (Tables 4, $5 \& 6$ ). In contrast, the susceptible control FiberMax 966 exhibited high gall and egg mass numbers, number of eggs per $\mathrm{g}$ of roots and high RF for all the populations (Tables $4,5 \& 6$ ), with two of the populations ( 8 and 10) standing out from the others as highly aggressive, reaching a RF of 539.3 and 218.0 

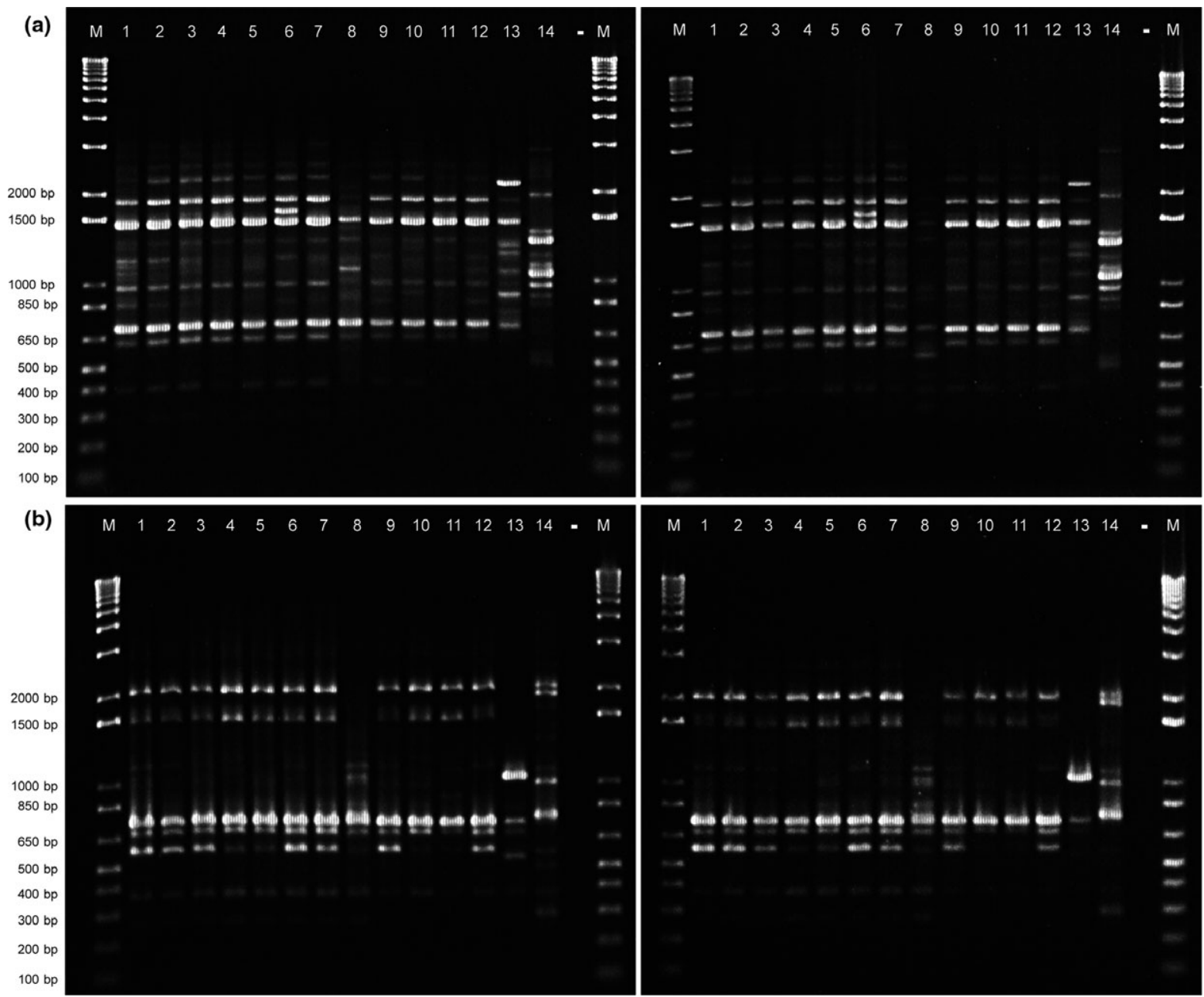

Figure 2 Genetic diversity of Meloidogyne incognita analysed with primers RAPD Z4 (a) and AFLP 18 (b); left and right panels show duplicates of the same RAPD/AFLP primer. 1-10: isolates from Bahia; 11 and 12: isolates from Paraná; 13: isolate from Mato Grosso do Sul; 14: M. enterolobii (out-group); (-): DNA negative control; M: 1 kb Plus DNA Ladder (Invitrogen); bp: base pairs.

Table 3 Percentage of polymorphisms detected in Meloidogyne incognita at population level.

\begin{tabular}{|c|c|c|c|c|c|c|}
\hline \multirow[b]{2}{*}{ M. incognita populations } & \multicolumn{2}{|c|}{ RAPD fragments } & \multicolumn{2}{|c|}{ AFLP fragments } & \multicolumn{2}{|c|}{ RAPD + AFLP fragments } \\
\hline & Amplified & Polymorphic (\%) & Amplified & Polymorphic (\%) & Amplified & Polymorphic (\%) \\
\hline $1-10 ; 11 ; 12 ; 13$ & 621 & $289(46.5)$ & 199 & $72(36.2)$ & 820 & $361(44.0)$ \\
\hline $1-10$ (excluding 8 ); 11; 12; 13 & 603 & $235(39.0)$ & 185 & $33(17.8)$ & 788 & $268(34.0)$ \\
\hline $1-10$ & 590 & $217(36.8)$ & 182 & $43(23.6)$ & 772 & $260(33.7)$ \\
\hline 1-10 (excluding 8) & 583 & $172(29.5)$ & 182 & $22(12.1)$ & 765 & $194(25.4)$ \\
\hline
\end{tabular}

aPopulation data in Table 1.

(means), respectively (Table 4). Comparing these results with the analysis of genetic variability (Fig. 3), the most aggressive population (8) was also the most genetically divergent for the RAPD and AFLP markers.

The correlation analysis between the evaluation parameters, performed using the Pearson coefficient (Table 7), showed a general significant positive correlation between GI, EMI, RF and eggs per g of roots; but for the resistant accessions CIR1348 and M-315 RNR there was a low correlation between GI/EMI, GI/eggs per $\mathrm{g}$ of roots, GI/RF, EMI/eggs per $\mathrm{g}$ of roots and EMI/RF. In accessions LA 887, Clevewilt 6 and Wild Mexican Jack Jones, a higher correlation was observed between EMI/RF than between GI/RF, and for all accessions RF/egg per $\mathrm{g}$ of roots had the highest correlation. 


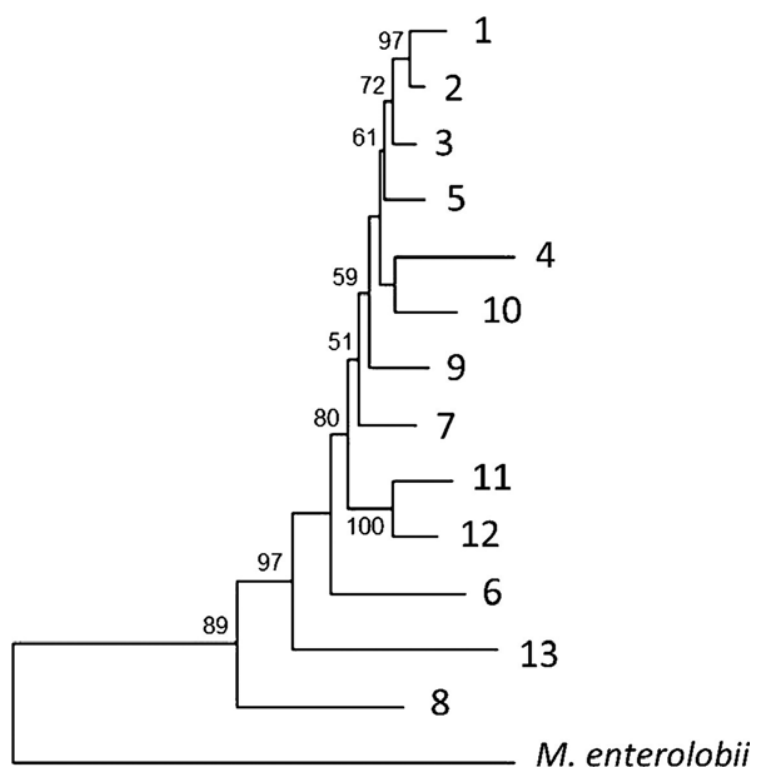

Figure 3 Phylogenetic tree of Meloidogyne incognita populations from Bahia (1-10); Paraná (11 and 12) and Mato Grosso do Sul (13) from RAPD and AFLP markers.

Table 4 Reproduction factor (RF) of six Meloidogyne incognita populations from Bahia state, Brazil, in cotton accessions with different levels of resistance.

\begin{tabular}{lrrrrrr}
\hline \multirow{2}{*}{$\begin{array}{l}\text { Cotton } \\
\text { accession }^{\mathrm{a}}\end{array}$} & \multicolumn{1}{l}{ Population $^{\mathrm{b}}$} & & & & \\
\cline { 2 - 7 } & \multicolumn{1}{c}{4} & 6 & \multicolumn{1}{l}{7} & 8 & 10 \\
\hline FiberMax 966 & $45.2 \mathrm{a}$ & $67.9 \mathrm{a}$ & $84.5 \mathrm{a}$ & $74.8 \mathrm{a}$ & $539.3 \mathrm{a}$ & $218 \mathrm{a}$ \\
Wild Mexican & $1.0 \mathrm{~b}$ & $2.7 \mathrm{~b}$ & $4.0 \mathrm{~b}$ & $5.0 \mathrm{~b}$ & $2.6 \mathrm{~b}$ & $4.1 \mathrm{~b}$ \\
Jack Jones & & & & & & \\
LA 887 & $0.3 \mathrm{~b}$ & $1.0 \mathrm{c}$ & $0.8 \mathrm{c}$ & $1.8 \mathrm{c}$ & $1.4 \mathrm{~b}$ & $0.8 \mathrm{c}$ \\
Clevewilt 6 & $0.3 \mathrm{~b}$ & $0.1 \mathrm{~d}$ & $0.1 \mathrm{~d}$ & $0.1 \mathrm{~d}$ & $1.3 \mathrm{~b}$ & $7.2 \mathrm{~b}$ \\
CIR1348 & $0.1 \mathrm{~b}$ & $0.0 \mathrm{~d}$ & $0.7 \mathrm{c}$ & $0.1 \mathrm{~d}$ & $0.1 \mathrm{c}$ & $0.7 \mathrm{c}$ \\
M-315 RNR & $0.0 \mathrm{~b}$ & $0.1 \mathrm{~d}$ & $0.0 \mathrm{~d}$ & $0.0 \mathrm{~d}$ & $0.0 \mathrm{c}$ & $0.0 \mathrm{~d}$ \\
\hline
\end{tabular}

Coefficient of variation $(\%)=40.7$.

${ }^{a}$ Cotton accessions described in Table 2.

${ }^{\mathrm{b}}$ Meloidogyne incognita population data in Table 1.

Mean values (7 plants per accession) are transformed as log $(x+1)$. Means followed by different letters within columns are significantly different $(P<0.05)$ according to Scott-Knot's test.

\section{Discussion}

This study evaluated the genetic variability and aggressiveness/virulence of 10 populations of M. incognita from Bahia state, Brazil and three populations from Paraná and Mato Grosso do Sul states, previously studied by Silva et al. (2014). Six populations from Bahia state were evaluated on different cotton cultivars that harbour resistance genes to RKN. Similar results have been reported for $M$. incognita on cotton from different Brazilian states (Silva et al., 2014) and for different populations from different crops (Santos et al., 2012). Despite the existence of three esterase profiles for
M. incognita (EST I1, I2 and S2) and a low genetic variability reported by Santos et al. (2012), only one phenotype (EST I2) was detected in all the populations, but high genetic diversity $(44 \%)$ was found, mainly due to population 8 , which differed significantly from the others. Removing this population from the analysis of variability, the genetic diversity was only $25 \%$. Meloidogyne incognita is known to have low genetic variability due its parthenogenetic reproduction and similarities in the chromosome number (Santos et al., 2012). Phylogenetically, all M. incognita Brazilian populations clustered together with $89 \%$ bootstrap support. In addition, the populations from Paraná remained together with $100 \%$ bootstrap support, but no other geographical relationship among populations of $M$. incognita from cotton was found. Similar results were also reported for other M. incognita isolates (Randig et al., 2002; Carneiro et al., 2004; Santos et al., 2012; Silva et al., 2014).

The identification of races in RKN is important not only for the characterization of resistance, but also for the development of management programmes in infested areas (Fassuliotis, 1985). The prevalence of race 3 in comparison to race 4 in cotton was reported for the first time by Silva et al. (2014), and the present results confirm that RKN populations from cotton, virulent to resistant tobacco NC 95 (race 4), are less frequent. Despite the existence of two races in these populations, which is important for the establishment of management strategies, Moens et al. (2009) recommended the discontinuation of this terminology. Indeed, this concept has never been universally accepted because it measures a very restricted portion of the potential variation in parasitic variability. In the present study, no relationship was observed among host races and genetic polymorphism or phylogeny. These findings suggest that race 4 (population 7) has low genetic polymorphism, which is in agreement with previous observations (Carneiro \& Cofcewicz, 2008). Recently, it was shown that the genomes of apomictic Meloidogyne are made of duplicated regions, with functional divergence between gene copies, and which are rich in transposable elements, which might be responsible for their genomic plasticity and adaptation to the environment (Blanc-Mathieu et al., 2017).

Population 8 was the most divergent and also highly aggressive to the susceptible cotton FiberMax 966. This correlation between aggressiveness and genetic variability was not observed in the other populations, as another aggressive population (10) did not present high genetic divergence. Previous studies have also failed to establish this correlation (Silva et al., 2014; Mattos et al., 2016). Aggressiveness reflects the ability of nematodes to reproduce on a susceptible host, as measured by the RF, whereas virulence is their ability to reproduce on resistant hosts (Hussey \& Janssen, 2002). Therefore, in this study, no $M$. incognita populations were virulent for cotton cultivars bearing resistance genes. According to Castagnone-Sereno (2002), genomic polymorphisms are independent of virulence, and are probably the result of independent mutational events. 
Table 5 Gall index (GI) and egg mass index (EMI) of six Meloidogyne incognita populations from Bahia state, Brazil, on selected cotton accessions.

\begin{tabular}{|c|c|c|c|c|c|c|c|c|c|c|c|c|}
\hline \multirow[b]{3}{*}{ Cotton accession ${ }^{\mathrm{a}}$} & \multicolumn{12}{|c|}{ Population $^{b}$} \\
\hline & \multicolumn{2}{|l|}{1} & \multicolumn{2}{|l|}{4} & \multicolumn{2}{|l|}{6} & \multicolumn{2}{|l|}{7} & \multicolumn{2}{|l|}{8} & \multicolumn{2}{|l|}{10} \\
\hline & $\overline{\mathrm{Gl}^{\mathrm{C}}}$ & $\mathrm{EMI}^{\mathrm{C}}$ & $\overline{\mathrm{Gl}}$ & $\overline{\text { EMI }}$ & $\overline{\mathrm{Gl}}$ & $\overline{\text { EMI }}$ & $\mathrm{Gl}$ & $\overline{E M I}$ & $\overline{\mathrm{Gl}}$ & $\overline{E M I}$ & $\overline{\mathrm{Gl}}$ & $\overline{\text { EMI }}$ \\
\hline FiberMax 966 & 5.0 & 5.0 & 5.0 & 5.0 & 5.0 & 5.0 & 5.0 & 5.0 & 5.0 & 5.0 & 5.0 & 5.0 \\
\hline Wild Mexican Jack Jones & 1.8 & 3.6 & 3.8 & 4.5 & 2.0 & 4.5 & 4.5 & 3.5 & 3.6 & 3.0 & 3.8 & 3.2 \\
\hline LA 887 & 3.3 & 4.7 & 4.0 & 4.2 & 4.8 & 4.4 & 4.4 & 2.8 & 4.7 & 2.7 & 4.0 & 1.4 \\
\hline Clevewilt 6 & 0.7 & 1.6 & 1.6 & 1.2 & 1.3 & 4.7 & 4.7 & 0.4 & 1.6 & 0.4 & 1.6 & 0.4 \\
\hline CIR1348 & 0.1 & 0.8 & 1.3 & 0.0 & 0.8 & 0.4 & 0.4 & 0.0 & 0.8 & 0.0 & 1.3 & 1.3 \\
\hline M-315 RNR & 0.0 & 0.4 & 0.0 & 0.3 & 0.0 & 0.1 & 0.1 & 0.0 & 0.4 & 0.0 & 0.0 & 0.0 \\
\hline
\end{tabular}

${ }^{\mathrm{a} C}$ Cotton accession data in Table 2 .

${ }^{\mathrm{b}}$ Meloidogyne incognita population data in Table 1.

${ }^{c}$ Mean values (7 plants per accession) of GI or EMI. 0: no gall or egg-mass, 1: 1-2 galls or egg-masses, 2: 3-10 galls or egg-masses, 3: 11-30 galls or egg-masses, 4: 31-100 galls or egg-masses, and 5: >100 galls or egg-masses per root system (Hartman \& Sasser, 1985).

Table 6 Eggs per g of roots of six Meloidogyne incognita populations from Bahia state, Brazil, in cotton accessions with different levels of resistance.

\begin{tabular}{|c|c|c|c|c|c|c|}
\hline \multirow[b]{2}{*}{ Cotton accession ${ }^{\mathrm{a}}$} & \multicolumn{6}{|c|}{ Population $^{b}$} \\
\hline & 1 & 4 & 6 & 7 & 8 & 10 \\
\hline FiberMax 966 & $3844.9 \mathrm{a}$ & $5264.0 \mathrm{a}$ & $7494.5 \mathrm{a}$ & $4985.5 \mathrm{a}$ & $33104.5 \mathrm{a}$ & $13563.4 \mathrm{a}$ \\
\hline Wild Mexican Jack Jones & $52.7 \mathrm{~b}$ & $156.1 \mathrm{~b}$ & $236.4 \mathrm{~b}$ & $270.8 b$ & $82.1 \mathrm{~b}$ & $203.1 \mathrm{C}$ \\
\hline LA 887 & $19.1 \mathrm{~b}$ & $46.9 \mathrm{~b}$ & $47.7 \mathrm{c}$ & $100.6 \mathrm{~b}$ & $75.0 \mathrm{~b}$ & $57.0 \mathrm{~d}$ \\
\hline Clevewilt 6 & $12.1 \mathrm{~b}$ & $2.8 \mathrm{c}$ & $4.1 \mathrm{~d}$ & $2.9 \mathrm{c}$ & $35.4 \mathrm{~b}$ & $560.8 \mathrm{~b}$ \\
\hline CIR1348 & $3.9 \mathrm{c}$ & $0.8 \mathrm{c}$ & $35.7 \mathrm{c}$ & $6.9 \mathrm{c}$ & $4.8 \mathrm{c}$ & $38.7 \mathrm{~d}$ \\
\hline M-315 RNR & $1.5 \mathrm{c}$ & $2.8 \mathrm{c}$ & $1.1 \mathrm{~d}$ & $0.0 d$ & $0.7 \mathrm{c}$ & $0.4 \mathrm{e}$ \\
\hline
\end{tabular}

Coefficient of variation $(\%)=29.7$.

${ }^{\mathrm{a} C}$ Cotton accession data in Table 2 .

${ }^{\mathrm{b}}$ Meloidogyne incognita population data in Table 1.

Mean values (7 plants per accession) are transformed as $\log (x+1)$. Means followed by different letters within columns are significantly different $(P<0.05)$ according to Scott-Knot's test.

Table 7 Correlation coefficients between the evaluation parameters for the six cotton accessions.

\begin{tabular}{|c|c|c|c|c|c|c|c|}
\hline Cotton accession ${ }^{a}$ & Statistic & $\mathrm{GI} / \mathrm{EMl}$ & Gl/eggs per $\mathrm{g}$ of roots & $\mathrm{Gl} / \mathrm{RF}$ & $\begin{array}{l}\text { EMl/eggs per } \\
\mathrm{g} \text { of roots }\end{array}$ & $\mathrm{EMI} / \mathrm{RF}$ & $\begin{array}{l}\text { RF/eggs per } \\
\mathrm{g} \text { of roots }\end{array}$ \\
\hline \multirow[t]{2}{*}{ LA 887} & $r^{b}$ & 0.6719 & 0.3768 & 0.3994 & 0.6081 & 0.6416 & 0.9693 \\
\hline & $P^{c}$ & $<0.0001$ & 0.0139 & 0.0088 & $<0.0001$ & $<0.0001$ & $<0.0001$ \\
\hline \multirow[t]{2}{*}{ Clevewilt 6} & $r$ & 0.8792 & 0.6547 & 0.6795 & 0.7261 & 0.7645 & 0.9869 \\
\hline & $P$ & $<0.0001$ & $<0.0001$ & $<0.0001$ & $<0.0001$ & $<0.0001$ & $<0.0001$ \\
\hline \multirow[t]{2}{*}{ Wild Mexican Jack Jones } & $r$ & 0.8054 & 0.5501 & 0.512 & 0.7428 & 0.7729 & 0.9799 \\
\hline & $P$ & $<0.0001$ & 0.0002 & 0.0005 & $<0.0001$ & $<0.0001$ & $<0.0001$ \\
\hline \multirow[t]{2}{*}{ CIR1348 } & $r$ & 0.3804 & 0.252 & 0.1925 & 0.2276 & 0.0524 & 0.9727 \\
\hline & $P$ & 0.0130 & 0.1068 & 0.2220 & 0.3862 & 0.2419 & $<0.0001$ \\
\hline \multirow[t]{2}{*}{ M-315 RNR } & $r$ & $=$ & 0.4523 & 0.4504 & $=$ & $=$ & 0.8834 \\
\hline & $P$ & & 0.0028 & 0.0026 & & & $<0.0001$ \\
\hline \multirow[t]{2}{*}{ FiberMax 966} & $r$ & $=$ & $=$ & $=$ & $=$ & $=$ & 0.9082 \\
\hline & $P$ & & & & & & $<0.0001$ \\
\hline
\end{tabular}

GI, gall index; EMI, egg mass index; RF, reproduction factor; =, indicates standard deviation of 0 .

${ }^{a}$ Cotton accession data in Table 2.

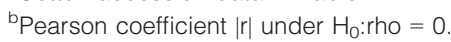

cSignificance level.

All cotton accessions were resistant to the populations of M. incognita from Bahia, according to the concepts of Hussey \& Janssen (2002), where RF below $10 \%$ in relation to the susceptible control is considered resistant. These results demonstrate a strong effect of available resistance genes against populations prevalent on cotton 
farms in Bahia. The presence of one QTL associated with RKN resistance (Wild Mexican Jack Jones, Clevewilt 6 and LA 887) is sufficient to drastically reduce the nematode population, whereas the combination of two QTLs (CIR1348 and M315) leads almost to immunity, even considering highly aggressive populations (8 and 10). This information corroborates the possibility of using available elite strains possessing only one resistance QTL in the management of M. incognita in the west of Bahia in the short term. However, although there was a high population reduction, it is important to note that accessions with only one resistance gene allow low reproduction of the nematode. Unrestricted use of it in the long term can lead to the emergence of virulent populations. Resistance based on a few genes may impose a selection pressure on nematode populations and hasten the selection of virulent isolates, as has been observed in other crops (Janssen et al., 1990). Parthenogenetic species of RKN have a highly adaptive responsiveness to the environment, and their ability to overcome resistance genes has been demonstrated (Roberts, 1995; Castagnone-Sereno, 2002).

A low correlation was found between the number of eggs per $g$ of roots and the GI, showing that, depending on the cultivar, the values may not be correlated. This means that the assessment of cultivars regarding resistance to RKN based only on GI can lead to errors, which can be explained by the fact that in several cases the resistance response is late, allowing gall development but preventing the formation of egg masses (Mota et al., 2013). The findings here reinforce the need to use combined parameters to evaluate the RKN resistance.

The high level of resistance to $M$. incognita found in the cotton breeding line M-315 RNR and in other lines derived from the same source (Auburn 634 RNR), has not been transferred to superior varieties. This resistance is inherited from two major genes, presumably one from Clevewilt 6 and the other from Wild Mexican Jack Jones (McPherson et al., 2004; Starr et al., 2010). Clevewilt 6 has one recessive resistance gene that confers moderate resistance to M. incognita (McPherson et al., 2004), and it is also believed to be the source of resistance in LA 887 (Jones et al., 1990). The same resistance allele is present in some of the cultivars in Brazil (P. Barroso, Embrapa Territorial Intelligence, Brazil, personal communication), pointing to the need for more efficient resistance gene combinations. All the populations tested were avirulent to M-315 RNR, and all these harbour a second gene in addition to that originating from Clevewilt- 6 . The resistance present in Wild Mexican Jack Jones has never been deployed in varieties cultivated in Brazil. Interestingly, this accession showed a high level of resistance to all populations, even to the most aggressive ones. The other accessions that showed high levels of resistance to all populations in this study were LA 887 and CIR1348, and they also constitute potential sources of resistance that have, to the best of the authors' knowledge, never been deployed in commercial cultivars in Brazil. In the present study, it has been shown that these sources of resistance could have a large adaptability.
Further studies are underway to find out whether the resistance gene(s) and allele(s) in LA 887 and CIR1348 are different from those present in Auburn 634 RNR and in the derived germplasm. The characterization of new M. incognita populations from Bahia and identification of novel sources of resistance that can be pyramided and/or rotated is an important goal towards the effective and durable management of RKN on cotton farms.

\section{Acknowledgements}

This work was supported by Associação dos Produtores de Algodão da Bahia (ABAPA), EMBRAPA - Recursos Genéticos e Biotecnologia, EMBRAPA - Algodão, Coordenação de Aperfeiçoamento de Pessoal de Nível Superior (CAPES) and Conselho Nacional de Desenvolvimento Científico e Tecnológico (CNPq). Special thanks to Dr Marc Giband for providing the cotton germplasm.

\section{References}

Blanc-Mathieu R, Perfus-Barbeoch L, Aury J-M et al., 2017. Hybridization and polyploidy enable genomic plasticity without sex in the most devastating plant-parasitic nematodes. PLoS Genetics 13, e1006777.

Carneiro RMDG, Almeida MRA, 2001. Técnica de eletroforese usada no estudo de enzimas dos nematoides de galhas para identificação de espécie. Nematologia Brasileira 25, 35-44.

Carneiro RMDG, Cofcewicz ET, 2008. Taxonomy of coffee-parasitic root-knot nematodes, Meloidogyne spp. In: Souza RM, ed. Plant Parasitic Nematodes of Coffee. New York, NY, USA: APS Press \& Springer, 87-122.

Carneiro RMDG, Tigano MS, Randig O, Almeida MRA, Sarah JL, 2004. Identification and genetic diversity of Meloidogyne spp. (Tylenchida: Meloidogynidae) on coffee from Brazil, Central America and Hawaii. Nematology 6, 287-98.

Castagnone-Sereno P, 2002. Genetic variability of nematodes: a threat to the durability of plant resistance genes? Euphytica 124, 193-9.

CONAB - Companhia Nacional de Abastecimento, 2018.

Acompanhamento da safra brasileira de grãos. Oitavo levantamento de safra 2017/18. Conab 3, 1-145.

Fassuliotis G, 1985. The role of the nematologists in the development of resistant cultivars. In: Barker KR, Carter CC, Sasser JN, eds. An Advanced Treatise on Meloidogyne. Raleigh, NC, USA: North Carolina State University Graphics, 233-40.

Galbieri R, Inomoto MM, Silva RA, 2015. Manejo de nematoides na cultura do algodoeiro em Mato Grosso. In: Belot JL, ed. Manual de Boas Práticas de Manejo do Algodoeiro em Mato Grosso. Cuiabá, Brazil: IMAMT 2, 214-25.

Hartman RM, Sasser JN, 1985. Identification of Meloidogyne species on the basis of differential host test and perineal pattern morphology. In: Barker KR, Carter CC, Sasser JN, eds. An Advanced Treatise on Meloidogyne. Raleigh, NC, USA: North Carolina State University Graphics, 69-77.

He Y, Kumar P, Shen X et al., 2014. Re-evaluation of the inheritance for root-knot nematode resistance in the upland cotton germplasm line $\mathrm{M}$ 120 RNR revealed two epistatic QTLs conferring resistance. Theoretical and Applied Genetics 127, 1343-51.

Hussey RS, Barker KR, 1973. A comparison of methods of collecting inocula of Meloidogyne spp., including a new technique. Plant Disease Reports 57, 1025-8.

Hussey RS, Janssen GJW, 2002. Root-knot nematodes: Meloidogyne species. In: Starr JL, Cook R, Bridge J, eds. Plant Resistance to Parasitic Nematodes. Wallingford, UK: CAB International, 43-70. Inomoto MM, 2001. Algodão: atacado por nematoides. Revista Cultivar 3, 5-7. 
Janssen R, Barker J, Gommers FJ, 1990. Selection of virulent and avirulent lines of Globodera rostochiensis for the $H 1$ resistance gene in Solanum tuberosum ssp. andigena CPC 1673. Revue de Nématologie 13, 265.

Jenkins JN, McCarty JC, Wubben MJ et al., 2012. SSR markers for marker assisted selection of root-knot nematode (Meloidogyne incognita) resistant plants in cotton (Gossypium hirsutum L.). Euphytica 183, 49-54.

Jones JE, Dickson JL, Aguillar W, Caldwell WD, More SH, Hutchinson RI, 1990. Stoneville LA 887: a new cotton variety. Louisiana Agriculture 33, 5.

Mattos VS, Furlanetto C, Silva JGP et al., 2016. Meloidogyne spp. populations from native cerrado and soybean cultivated areas: genetic variability and aggressiveness. Nematology 18, 505-15.

McPherson MG, Jenkins JN, Watson CE, McCarty JC, 2004. Inheritance of root-knot nematode resistance in M-315 RNR and M78-RNR cotton. Journal of Cotton Science 8, 154-61.

Moens M, Perry RN, Starr JL, 2009. Meloidogyne species - a diverse group of novel and important plant parasites. In: Perry RN, Moens M, Starr JL, eds. Root-knot Nematodes. Wallingford, UK: CABI International, 1-17.

Mota FC, Alves GCS, Giband M et al., 2013. New sources of resistance to Meloidogyne incognita race 3 in wild cotton accessions and histological characterization of the defense mechanisms. Plant Pathology 62, 1173-83.

Ogallo JL, Goodell PB, Eckert J, Roberts PA, 1997. Evaluation of Nem $\mathrm{X}$, a new cultivar of cotton with high resistance to Meloidogyne incognita. Journal of Nematology 29, 531-7.

Randig O, Bongiovanni M, Carneiro RMDG, Castagnone-Sereno P, 2002. Genetic diversity of root-knot nematodes from Brazil and development of SCAR markers specific for the coffee-damaging species. Genome 45, 862-70.

Roberts PA, 1995. Conceptual and practical aspects of variability in root-knot nematodes related to host plant resistance. Annual Review of Phytopathology 33, 199-221.
Santos MFA, Furlanetto C, Carneiro MDG et al., 2012. Biometrical, biological, biochemical and molecular characteristics of Meloidogyne incognita isolates and related species. European Journal of Plant Pathology 134, 671-84.

Semblat JP, Wajnberg E, Dalmasso A, Abad P, Castagnone-Sereno P, 1998. High-resolution DNA fingerprinting of parthenogenetic rootknot nematodes using AFLP analysis. Molecular Ecology 7, 119-25.

Shepherd RL, 1974. Transgressive segregation for root-knot nematode resistance in cotton. Crop Science 14, 872-5.

Silva EH, Mattos VS, Furlanetto C et al., 2014. Genetic variability and virulence of Meloidogyne incognita populations from Brazil to resistant cotton genotypes. European Journal of Plant Pathology 139, 195-204.

Starr JL, Moresco ER, Smith CW, Nichols RL, Roberts PA, Chee P, 2010. Inheritance of resistance to Meloidogyne incognita in primitive cotton accessions from Mexico. Journal of Nematology 42, 352-8.

Suazo A, Hall HG, 1999. Modification of the AFLP protocol applied to honey bee (Apis mellifera L.) DNA. BioTechniques 26, 704-9.

Swofford DL, 2002. PAUP *. Phylogenetic Analysis Using Parsimony ("and Other Methods). Sunderland, MA, USA: Sinauer Associates.

Trudgill DL, Blok VC, 2001. Apomictic, polyphagous root-knot nematodes: exceptionally successful and damaging biotrophic root pathogens. Annual Review of Phytopathology 39, 53-77.

Wang C, Roberts PA, 2006. A Fusarium wilt resistance gene in Gossypium barbadense and its effect on root-knot nematode-wilt disease complex. Phytopathology 96, 727-34.

Zhou E, Wheeler TA, Starr JL, 2000. Root galling and reproduction of Meloidogyne incognita isolates from Texas on resistant cotton genotypes. Journal of Nematology 32, 513-18.

Ziljstra C, Donkers-Venne DTHM, Fargette M, 2000. Identification of Meloidogyne incognita, M. javanica and M. arenaria using sequence characterised amplified regions (SCAR) based PCR assays. Nematology 2, 847-53. 